\title{
ESTABLISHING THE PRESENCE OF VINE THRIPS IN VINEYARDS OF SVETI IVAN ZELINA
}

\author{
UTVRĐIVANJE PRISUTNOSTI LOZINOG TRIPSA \\ U VINOGRADIMA SVETOG IVANA ZELINE
}

\author{
Ivana Pajač Živković, Ivana Miklečić, Darija Lemić
}

\begin{abstract}
The vine thrips feed on vegetative and generative organs of the grapevine and cause damage in production. At the beginning of vegetation they suck on the grapevine shoots and so they lag behind in growth. Later, they feed on the leaves, and spotted necrosis is observed at the sucking sites. Later light yellow leaf coloration can be seen. Attack signs can also be noticed on the berries and since there is usually aesthetic damage table grape varieties suffer the most.

Although the pest has been present in Croatia since the 1980s, little is known about the flight dynamics and the population size of this species. This study investigated the catch dynamics and population size of vine thrips in two vineyards (Gradunje and Vrškojice) in the area of Sveti Ivan Zelina. The thrips population was monitored during the vegetation season of 2018 by fluorescent yellow sticky traps $\left(\right.$ Csalomon $\left.{ }^{\circledR}\right)$. In both vineyards pest presence was established at the beginning of May, and the last catches were recorded in the second half of September. According to the catch dynamics, the pest develops three generations in the investigated vineyards, and the highest number of thrips was recorded in the phase of growth and development of berries. Given the established thrips populations, its control is recommended, and in Croatia for this purpose only insecticide based on the active substance spinetoram has been registered.
\end{abstract}

Key words: catch dynamics, Drepanothrips reuteri Uzel, fluorescent yellow sticky traps, grapevine

\section{SAŽETAK}

Lozin trips hrani se vegetativnim i generativnim organima vinove loze i uzrokuje štete u proizvodnji grožđa. Početkom vegetacije siše na izbojima vinove loze koji zaostaju u rastu. Kasnije se hrani na lišću, a na mjestima sisanja 
Ivana Pajač Živković i sur.: Establishing the presence of vine thrips in vineyards of Sveti Ivan Zelina

uočavaju se točkaste nekroze, te list poprima svjetložutu boju. Štete se mogu uočiti i na bobicama, a najviše stradavaju stolne sorte jer su oštećenja estetske prirode. Iako je štetnik prisutan u Hrvatskoj od 1980-ih malo se zna o dinamici leta $\mathrm{i}$ brojnosti populacije ove vrste. $\mathrm{U}$ radu se istražuje dinamika ulova $\mathrm{i}$ veličina populacije lozinog tripsa u dva vinograda (Gradunje i Vrškojice) na području Svetog Ivana Zeline. Populacija štetnika praćena je tijekom vegetacijske sezone u 2018. godini florescentno žutim ljepljivim pločama (Csalomon $\left.{ }^{\circledR}\right)$. U oba vinograda prisutnost štetnika utvrđena je početkom svibnja, a posljednje jedinke ulovljene su u drugoj polovici rujna. Prema dinamici ulova štetnik $u$ istraživanim vinogradima razvija tri generacije, a najveća brojnost zabilježena je u fazi razvoja i sazrijevanja bobica. S obzirom na utvrđenu brojnost populacije tripsa preporuča se njegovo suzbijanje, a u Hrvatskoj je u tu svrhu registriran jedino pripravak na bazi aktivne tvari spinetoram.

Ključne riječi: dinamika ulova, Drepanothrips reuteri Uzel, florescentno žute ljepljive ploče, vinova loza

\section{INTRODUCTION}

Drepanothrips reuteri Uzel, 1895 is a polyphagous pest which feeds on deciduous trees and fruits (Jenser et al. 2010). In agronomy, it is a pest which causes damage on vegetative and generative organs of the grapevine (Ciglar and Žužić 1990). According to Mound, 1997 (cit. Marullo 2009) vine thrips originally fed on species in the genus Quercus, but due to evolutionary changes it changed feeding habits, and started feeding on vine and other cultivated plant species. Vine thrips initially thrived on the riverbank grape (Vitis riparia Michx.), as well as their crossbreeds, and from the riverbank grape they spread to noble varieties of European grapevine (Ciglar and Žužić 1990; Maceljski et al. 2006).

Vine thrips was observed for the first time in 1926 in North America, in California (Winkler et al. 1974) and Bailey (1942) was the first to describe the species. Nowadays, the pest is present in many European countries and in the last decades its damage on the shoots and grapes increased (Jenser et al. 2010). In Croatia, this species was observed for the first time in the vineyards in the area surrounding Poreč during the 1980s, and later on its presence was determined in the vineyards of the Zadar region and the area of continental Croatia (Jastrebarsko, Voloder, Vukovar and others) (Ciglar and Žužić 1990). 
Vine thrips is a very small insect, measuring less than $1 \mathrm{~mm}$, with a lightyellow body color and with red eyes (Ciglar and Žužić, 1990; Maceljski et al., 2006). The biggest damage is caused by grown females that overwinter under the vine bark and that in the spring, during early vegetation, attack early fruits of the grapevine (Jenser et al. 2010). The damage manifests as necrotic spots on the leaf blade, the petiole, and the berries (Ciglar and Žužić 1990). The pest especially lingers on the top leaves which assume the light yellow colour and are different in shape (Yokoyama 1977; Ciglar and Žužić 1990). On the already formed berries, vine thrips leave behind ring shaped or linear shaped red stains (Roditakis and Roditakis 2007).

Damage from vine thrips is significant in those vineyards in which table grapes varieties dominate. There, one can also find visible signs of damage on up to $50 \%$ of berries (Bailey 1942). On berries, there is usually aesthetic damage (Skinkis et al. 2017), which reduces the market value of grapevine and limits international trade due to danger from the spread of the pest (Özsemerci et al. 2011).

In Hungary, vine thrips grow three to four generations a year that overlap (Jenser et al. 2010). According to Ciglar and Žužić (1990) in Croatia pest can develop one to three generations a year. The biggest abundance of this species in Romania was found in the flowering phenophase of the grapevine (VasiliuOromulu et al. 2009). In the phenophase of the growth and maturation of the berries, the number of the species is reduced, and during the full maturation of the berries, the pest no longer appears (Vasiliu-Oromulu et al. 2009).

During the vegetative season vine thrips are mostly attracted to fluorescent yellow sticky traps which, apart from determining the pest presence, also serve as a reliable method of the flight dynamics monitoring (Jenser et al. 2010). The catch efficiency of the mentioned traps is also recorded in conditions of reduced population density of vine thrips (Addante et al. 1995).

According to Ciglar (1998) pest control is carried out depending on the size of the population at the beginning of vegetation season and for this purpose only one insecticide based on the active substance spinetoram is licensed.

Since the vine thrips population has never been explored in Croatia the aim of research was to determine flight dynamics and link its seasonal occurrence with developmental phases of grape vine. 
Ivana Pajač Živković i sur.: Establishing the presence of vine thrips in vineyards of Sveti Ivan Zelina

\section{MATERIALS AND METHODS}

\section{Study area}

The study was conducted in two vineyards situated in northwestern part of Croatia (Zagreb County). The vineyards (Gradunje and Vrškojice) are $1000 \mathrm{~m}$ apart and are located in the area of Sveti Ivan Zelina $\left(45^{\circ} 57^{\prime} 34.64 " \mathrm{~N}\right.$, $\left.16^{\circ} 14^{\prime} 35.02 " \mathrm{E}\right)$. Research area is in the Prigorje - Bilogora subregion. The climate of this vine growing area is moderately continental, with an average annual air temperature of $10-12{ }^{\circ} \mathrm{C}$. The lowest average air temperature is recorded in January and the highest in July. The average annual precipitation varies between 800 and $1000 \mathrm{~mm}$ (CMS, 2018) and this climate favors the development of the vine. At experimental sites chemical treatments (insecticides and fungicides) were applied by standard IPM principles several times in the season to control vine moths and fungal diseases. Weeds were managed by mulching treatments between rows, and vegetation in the row was not treated with herbicides.

\section{Thrips sampling and identification}

The thrips population was monitored by Szz fluorescent yellow sticky traps produced by the Hungarian company Csalomon ${ }^{\circledR}$. The sticky traps contained dimensions of $16 \times 10 \mathrm{~cm}$, and their total sticky surface spread on approximately $320 \mathrm{~cm}^{2}$. In the middle of every vineyard, there was one trap attached to the galvanised wire at the height of $180 \mathrm{~cm}$. The monitoring of the vine thrips started on the $1^{\text {st }}$ of April and lasted until the $22^{\text {nd }}$ of September 2018. The traps were examined on a weekly basis, and the caught thrips were washed with the gasoline used for cleaning. Then, they were conserved until the identification in glass tubes containing AGA solution (10 units of $60 \%$ ethylalcohol, 1 unit of glycerol and 1unit of glacial acetic acid).

Collected thrips specimens were slide mounted in Canada balsam according to the standard method (Mound and Kibby, 1998) and examined using an Olympus BX 51 microscope, equipped with a DP 25 Digital Camera. Thrips were identified to the species level based on microscopic morphological characters by using identification key Zur Strassen (2003) at the laboratory of the Center for Plant Protection of the Croatian Agency for Agriculture and Food. 
Ivana Pajač Živković i sur.: Establishing the presence of vine thrips in vineyards of Sveti Ivan Zelina

\section{RESULTS AND DISCUSSION}

In the vineyards Gradunje and Vrškojice the first catch of vine thrips was documented on the $5^{\text {th }}$ of May 2018 (Gradunje 72, Vrškojice 49 specimens) (Fig. 1.). In subsequent examinations, the pest populations abundance was on the rise, and on the $26^{\text {th }}$ of May 2018, the first peak of populations (Gradunje 226, Vrškojice 251) was recorded. Following the $2^{\text {nd }}$ of June 2018, a slight drop in populations was recorded (Gradunje 176, Vrškojice 153). Another slight rise during the examination on the $23^{\text {rd }}$ of June 2018 was recorded (Gradunje 263, Vrškojice 249) and on the $9^{\text {th }}$ of July 2018, a sudden drop in the pest population was observed which lasted until the end of July (Fig. 1.). The second pest population peak was recorded on the $4^{\text {th }}$ of August, 2018 (Gradunje 314, Vrškojice 406), but already upon the next examination (the $11^{\text {th }}$ of August, 2018), a sudden drop in their number was visible (Fig. 1.). The third peak of populations was observed on the $25^{\text {th }}$ of August 2018 (Gradunje 201, Vrškojice 220) with gradual drop until the end of September (Fig. 1.).

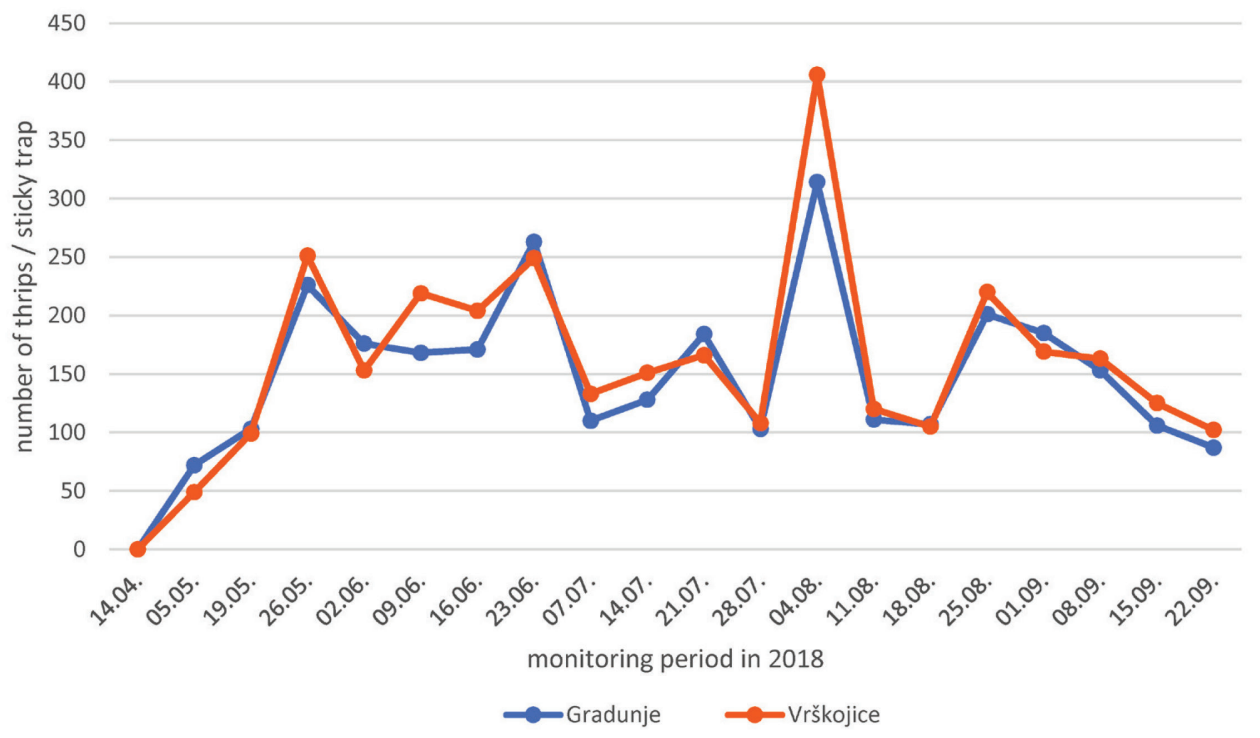

Fig. 1 Catch dynamics of vine thrips in vineyards Gradunje and Vrškojice during the monitoring period in 2018

Slika 1. Dinamika ulova lozinog tripsa u vinogradima Gradunje i Vrškojice tijekom perioda praćenja u 2018. godini 
Ivana Pajač Živković i sur.: Establishing the presence of vine thrips in vineyards of Sveti Ivan Zelina

Research in Hungary (Jenser et al. 2010) has shown that, depending on the vegetative season, the vine thrips population that overwintered was present in the vineyard from the middle of April until the middle of May, which corresponds with this research, in which the first pest population that overwintered was identified at the beginning of May. Since the pest population dynamics have not been researched in Croatia yet, on the basis of data gathered by this research vine thrips develops three generations per year, and the population number is closely connected with the phases of the grapevine growth (Vasiliu-Oromulu et al. 2009; Özsemerci et al. 2011).

In Table 1, the total catches of vine thrips in the vineyards concerning the documented phases of grapevine growth are shown. During the phases of budding, growth and development of the vegetation the lowest population number was observed while the highest number was recorded in the phase of the growth and development of the berries (Table 1).

Table 1 Vine thrips catches concerning developmental phases of grape vine during the investigation period in 2018 in the vineyards of Sveti Ivan Zelina

Tablica 1. Ulovi lozinog tripsa u odnosu na razvojne faze vinove loze tijekom istraživanog razdoblja 2018. godine u vinogradima Svetog Ivana Zeline

\begin{tabular}{|c|c|c|}
\hline \multirow{2}{*}{$\begin{array}{c}\text { Developmental phases of grape vine } \\
\text { during the reviewing period in } 2018\end{array}$} & \multicolumn{2}{|c|}{ thrips caught $/$ vineyard } \\
\cline { 2 - 3 } $\begin{array}{c}\text { Gradunje } \\
\text { budding, growth and development of the vegetation } \\
\left(1^{\text {st }} \text { April }-19^{\text {th }} \text { May }\right)\end{array}$ & 175 & 148 \\
\hline $\begin{array}{c}\text { flowering and fertilisation } \\
\left(20^{\text {th }} \text { May }-2^{\text {nd }} \text { June }\right)\end{array}$ & 402 & 404 \\
\hline $\begin{array}{c}\text { growth and development of berries } \\
\left(3^{\text {rd }} \text { June }-18^{\text {th }} \text { August }\right)\end{array}$ & 1659 & 1861 \\
\hline $\begin{array}{c}\text { grapes maturation } \\
\left(19^{\text {th }} \text { August }-22^{\text {nd }} \text { September }\right)\end{array}$ & 732 & 779 \\
\hline vine thrips caught in total & $\mathbf{2 9 6 8}$ & $\mathbf{3 1 9 2}$ \\
\hline
\end{tabular}

In general, the total population abundance in investigated vineyards was similar and during the investigation period altogether 6160 adult specimens of vine thrips were identified (Table 1). 
Ivana Pajač Živković i sur.: Establishing the presence of vine thrips in vineyards of Sveti Ivan Zelina

According to similar research on this pest (McNally et al. 1985; Marullo, 2009, Vasiliu-Oromulu et al. 2009; Özsemerci et al. 2011), vine thrips occur in vineyards during the phases of budding, growth and development of the vegetation, flowering and fertilisation, growth and development of berries, and grapes maturation, which has also been corroborated by the results of this research. Concerning different microclimatic conditions of the grapevine growth, the population dynamics and the pest number differ in various European countries. Research on the vine thrips flight dynamics in Romania has shown that the pest population proves to be highest in the phase of the flowering of the grapevine (end of May and beginning of June). In subsequent developmental phases, that is, during the growth and development of berries (from the first half of June until the beginning of July), the number of pest samples is reduced, and in the phase of grapes maturation (beginning of August), vine thrips no longer appear (Vasiliu-Oromulu et al. 2009). Similar studies on the vine thrips population in Hungary have shown that the pest population significantly increased in the month of July and reached its maximum by the middle of August (unpublished research results). Results of this study show a similar tendency of population growth. Vine thrips populations in the vineyards of Sveti Ivan Zelina in the phenophase of growth and development of berries (by the middle of August) reached their maximum and the catch dynamics of the species in the subsequent periods gradually dropped by the end of the study period (Table 1).

The pest population determined by this research during the phase of flowering and the subsequent phase of growth and development could cause damage during the formation of berries in both vineyards, therefore, it would be advisable to carry out pest control measures at the beginning of vegetation.

\section{CONCLUSIONS}

The catch dynamics of the vine thrips population was determined by fluorescent yellow sticky traps in researched vineyards (Gradunje and Vrškojice) in the area of Sveti Ivan Zelina. During the vegetation season of 2018 three pest generations were observed in both vineyards. In general, the catch dynamics of vine thrips varied during the monitoring period depending on vine growth stages and the highest number of pest population was recorded in the phases of growth and development of berries posing a threat to grapevine cultivation, so control measures need to be applied and for this purpose insecticide based on the active substance spinetoram is licensed. 
Ivana Pajač Živković i sur.: Establishing the presence of vine thrips in vineyards of Sveti Ivan Zelina

\section{REFERENCES}

1. Addante R, De Corato U, Moleas T. (1995): Osservazioni su Drepanothrips reuteri e Thrips tabaci (Thysanoptera: Thripidae) su vite in Puglia. La Difesa delle Piante. 18(4): 283-290.

2. Bailey SF. (1942): The grape or vine thrips, Drepanothrips reuteri. Journal of Economic Entomology. 35(3): 382-386. doi: http://dx.doi.org/10.1093/jee/35.3.382

3. Ciglar I, Žužić I. (1990): Lozin trips-Drepanothrips reuteri Uzel sve češći štetnik u vinogradima. Glasnik zaštite bilja. 12: 422-423.

4. Ciglar I. (1998): Integrirana zaštita voćnjaka i vinograda. Zrinski d.d., Čakovec, pp. 237.

5. CMS, Croatian Meteorological Society (2018): Available at: http://www.meteohmd.hr/hr/aktualnosti/meteoroloska-postaja-krapina,103.html. Assesed on 20 June (2018).

6. Jenser G, Szita E, Szenasi A, Vörös G, Toth M. (2010): Monitoring the Population of Vine Thrips (Drepanothrips reuteri Uzel) (Thysanoptera: Thripidae) by Using Fluorescent Yellow Sticky Traps. Acta Phytopathologica et Entomologica Hungarica. 45(2): 329-335. doi: https://doi.org/10.1556/APhyt.45.2010.2.10

7. Maceljski M, Cvjetković B, Ostojić Z, Barić B. (2006): Štetočinje vinove loze. Zrinski d.d., Čakovec, pp. 207-259.

8. Marullo R. (2009): Host-plant ranges and pest potential: habits of some thrips species in areas of southern Italy. Bulletin of Insectology. 62(2): 253-255.

9. McNally PS, Fogg C, Flynn J, Horenstein J. (1985): Effects of Thrips (Thysanoptera: Thripidae) on Shoot Growth and Berry Maturity of 'Chenin Blanc' Grapes. Journal of Economic Entomology 78(1): 69-72. doi: $\mathrm{http}: / / \mathrm{dx}$.doi.org/10.1093/jee/78.1.69

10. Mound LA, Kibby G. (1998): Thysanoptera: An Identification Guide. 2nd Ed. CABI, Oxford and New York, pp. 70.

11. Roditakis E, Roditakis NE. (2007): Assessment of the damage potential of three thrips species on white variety table grapes - In vitro experiments. Crop Protection 26: 476-483. doi: http://dx.doi.org/10.1016/j.cropro.2006.04.020

12. Skinkis P, Walton V, DeFrancesco J, Edmunds B, Bell N. (2017): Grape Pests. PNW Insect Menagement Handbook, pp. 140-141.

13. Vasiliu-Oromulu L, Barbuceanu D, Ion S. (2009): The ecological study of Thrips populations in a Southern Romanian vineyard (Insecta: Thysanoptera). Acta entomologica Serbica. 14(1): 1-11. 
Ivana Pajač Živković i sur.: Establishing the presence of vine thrips in vineyards of Sveti Ivan Zelina

14. Yokoyama YV. (1977): Drepanothrips reuteri on Thompson Seedlees Grapes. Environmental Entomology. 1(6): 21-24.

15. Özsemerci F, Aksit T, Tunc I. (2011): Composition, seasonal abundance and within-plant distribution of Thysanoptera species associated with seedlees grapes (Sultana) in districts of Manisa, Turkey. Turkish Journal of Entomology. 35(1): 103-118.

16. Winkler AJ, Cook JA, Kliewer WM, Lider LA. (1974): General viticulture. University of California Press Berkeley and Los Angeles, California, pp. 503-556.

17. Zur Strassen R. (2003): Die terebranten Thysanoptera Europas und des Mittelmeer-Gebietes. Die Tierwelt Deutschlands 74. Goecke and Evers, Keltern, pp. 5-277.

\section{ACKNOWLEDGEMENTS}

The authors would like to thank PhD Mladen Šimala for helping to determine species $D$. reuteri.

\section{Author's address - Adresa autora:}

Ivana Pajač Živković, e-mail: ipajac@agr.hr

Ivana Miklečić,

Darija Lemić

University of Zagreb Faculty of Agriculture,

Department of Agricultural Zoology,

Svetošimunska cesta 25, 10000 Zagreb, Croatia
Received - primljeno:

19.09.2019. 
Ivana Pajač Živković i sur.: Establishing the presence of vine thrips in vineyards of Sveti Ivan Zelina 